\title{
Needs Analysis for Design of Augmentes Reality Assessment (ARA) in Higher Education
}

\author{
Elfitra $^{1, *}$ Tiur Malasari Siregar ${ }^{2}$ Suci Frisnoiry ${ }^{3}$ \\ 1,2,3 Universitas Negeri Medan, Jl. Williem Iskandar pasar V Medan 20221, Indonesia \\ *Corresponding author. Email: elfitra@unimed.ac.id
}

\begin{abstract}
In previous research, Augmented Reality-assisted learning media has been developed in responding to the educational challenges of the Industrial Revolution 4.0 and the results were greeted with positive enthusiasm from students, especially during the online learning period. However, in conducting the assessment, they still use general tools such as google forms or LMS provided by the university. This study aims to design an android-based assessment tool using Augmented Reality or Augmented Reality Assessment (ARA) to improve students' 4C skills which are the demands of 21 st century skills. This application was created as an effort to answer the demands of technological progress and online learning during a pandemic. In designing Augmented Reality, the initial stage of the assessment is to conduct analysis. The analysis phase is an activity carried out to analyze the needs of the learning process so that the developed product meets the target. The analysis applied is based on learning needs in improving 4C skills including appropriate and upto-date media. The demand for online learning during the pandemic and also blended learning before the pandemic became support in designing ARA. Conduct material analysis in order to be able to direct indicators of learning objectives that are able to improve 4C skills which will later be used as assessment instruments for the ARA.
\end{abstract}

Keywords: Need Analysis, ARA.

\section{INTRODUCTION}

In conditions where the world of education has penetrated the industrial revolution 4.0 and is slowly entering the 5.0 industrial revolution, the world of education faces enormous challenges and changes in adjusting its technology intake. As we know, education has an important role in determining the progress of a nation. Education is the main means of improving the quality of a country's human resources. The more advanced the quality of education, the more panda society, the more advanced the country [1].

Educational demands are increasingly complex with the situation over the past two years, where all countries have experienced a pandemic due to the spread of the corona virus (covid-19), which resulted in changes in the learning system. The world of education has been forced to transform in a short time in the management of learning. Whereas previously, learning could be done face-to-face directly, conditions now require that learning be carried out online to limit physical contact and break the chain of spread. The results of the study also show that educators must ensure that teaching and learning activities continue, even though students are at home.
The solution: educators are required to design learning media as an innovation by utilizing online media (online). This is in line with the government circular issued by the Minister of Education and Culture of the Republic of Indonesia No. 4 of 2020 concerning the Implementation of Education Policies in the Emergency Period for the Spread of Corona Virus Disease (Covid-19). [2]

As part of the national education system, universities also play an important role in the development of a nation. Universities have a significant contribution to improving the quality of human resources (HR) in a country. Universities have an important role in preparing human resources, namely by increasing the competence of graduates who have skills according to the 21 st century (learning and innovation skills) in addition to mastering science and technology in accordance with the fields they are involved in [3]. Therefore, universities are required to be able to carry out the Tridharma of higher education even though they are in a pandemic condition and also in harmony with the 21 st century.

P21 (partnership for 21st century learning) creates a 21st century learning framework where students are expected to have $4 \mathrm{c}$ skills, namely critical thinking, 
communication, collaboration, and creativity. The P21 document explained that it was first introduced in 2002 as a conclusion of feedback received from teachers, education experts, and business leaders in the US. This clearly describes the skills, knowledge, and expertise that 21 st century students must possess in order to succeed in the job market and in life. Therefore, it can be said that $4 \mathrm{c}$ skills are a mastery of soft skills whose daily implementation is more meaningful than mastering hard skills. [4]

Critical thinking skills include basic clarification skills, basic decision-making, conclusions, providing further explanation, estimation and integration, as well as additional abilities [5]. Critical thinking is the ability to systematically evaluate the weight of personal opinions and the opinions of others (Elaine B. Johnson, 2009: 182) [6]. Simply put, critical thinking is a process in which a person receives information and makes logical and rational judgments in terms of making decisions about that information.

Communication skills are abilities that must be mastered because communication is a social interaction that occurs between someone who conveys ideas. "Communication makes it easier for students to be able to articulate ideas or opinions orally or in writing so that listeners can receive messages appropriately and effectively" [7]. In the world of work, communication skills are needed to be able to complete various jobs, both individual and group work. This is because communication skills will be used to interact with friends, superiors, and stakeholders [8].

The ability to collaborate is defined as a form of cooperation to achieve a goal as a group. In learning, activities carried out collaboratively or in groups will be much more fun and easier to understand than acting individually. Therefore, collaborative skills are needed for each individual to make it easier to achieve goals.

Creative skills and innovation are the ability to create something new, either ideas or works. Creativity can also be interpreted as a multi-dimensional construction involving cognitive, personality, family, educational, and socio-cultural variables [9]. These skills will greatly assist an individual in achieving his success. Therefore, it is felt that $4 \mathrm{c}$ skills education needs to be developed in learning in the 21 st century so that graduates are able to compete globally.

Medan State University has an important role as a forum for developing 21st century skills. In the field of higher education, Medan State University (Unimed) has undergone a period of online learning during the implementation of Ministerial Decree No. 4 of 2020. Because Unimed had implemented blended learning before the pandemic, there are only improvement problems in online learning. The availability of a
Learning Management System managed by Unimed for learning, namely SIPDA, really helps lecturers in managing online learning. However, it is necessary to develop the quality and quantity of lecturers in order to improve the quality of online learning. Lecturers are important subjects in learning. They must have a number of skills in the fields of IT (information technology), communication, speed reading skills, and online learning tends to be boring and boring, so that lecturers are expected to be more creative, innovative in terms of using learning media, and more fun. [10]

In using SIPDA, lecturers must first prepare the device, starting from the lesson plan, teaching materials or supporting learning media. In the Unimed environment, especially in the Mathematics Education Study Program, the utilization of the LMS has been maximized as shown by the monitoring results of the LPPMP Faculty of Mathematics and Natural Sciences in 2020, as described below.

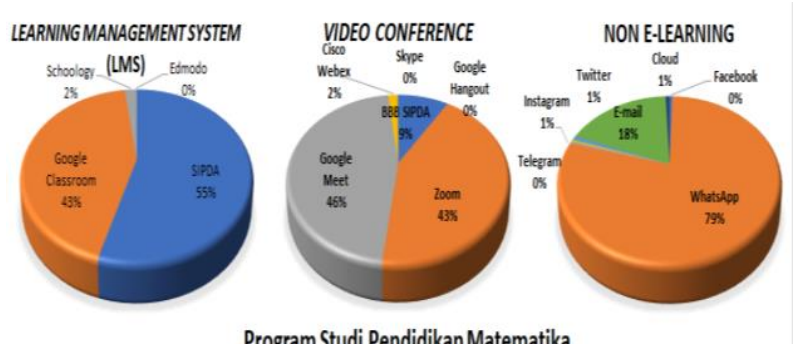

Program Studi Pendidikan Matematika

Figure 1 Online learning monitoring.

A study showed that activity-based teaching materials and resources at SIPDA unimed have been used effectively and have an impact on improving student learning behavior [11]. This research is supported by research which states that the online learning system for students at Unimed also affects student learning motivation [12]. In addition, the teaching media used in online learning is the influence of success, one of which is by using virtual video as a substitute for the presence of the teacher. This is supported by research which states that virtual video is a product that has a very good category as an online learning medium [13].

Students of the millennial generation tend to be easier to understand techniques in online learning with various digital media. One of the media in question is the media that uses Android. Besides that, Android-based learning media is good for use as a learning media [14]. The International Telecommunication Union (ITU) reports that $80 \%$ of teenagers (15-24) in 104 countries are online using mobile Smartphones [15]. The Ministry of Communication and Information explained that $89 \%$ of Indonesia's population uses Android. Therefore, the use of Android as an online learning support has become very useful. 
However, learning outcomes are not always in line with expectations. Even though the lecturers have prepared interactive learning media, there are still places where students can not understand or draw conclusions from the statements that have been provided. In a study, 164 respondents who were given video media showed an average ability of 51.2, still needing special attention and there needed to be improvements to the media provided [16].

The ultimate goal of learning is always measured by an assessment that is structured in the form of an evaluation. There are many evaluation platforms, both online and offline, that support online learning. The Google form is one of the most frequently used options because it is considered effective because it makes it easier for teachers and students to fill out questions and process data by the teacher. Google forms have advantages, such as providing an automatic data processing system, so that teachers do not need to calculate manually [17]. There is also an online Kahoot application which is a learning evaluation tool. The Kahoot application is worthy of being used as a daily evaluation tool where $81 \%$ of students stated that this application was very interesting to use [18].

Apart from all the platforms that are available, there is a need for innovation in the development of new evaluation media, one of which is by designing an Android-based assessment media. In previous studies, augmented reality learning media has been developed by considering the $4 \mathrm{c}$ skills needs that students must have. For this reason, an Android-based Augmented Reality Assessment (ARA) design is needed as an effort to improve students' $4 \mathrm{c}$ abilities in facing the 21 st century. Considering that Android-based AR design is an innovation that is in line with the needs of the times, where almost all students have Androids so they can maximize their Android functions as learning tools. In addition, the use of Augmented Reality in learning in the Mathematics and Natural Sciences environment is still very small. The assessment is expected to show the $4 \mathrm{C}$ measurement process that students need to face the world of work and global competition in the 21 st century. The reason for having to improve $4 \mathrm{C}$ skills is that the reality is that every graduate must face a dynamic future, full of challenges and changes, all of which will be forged by mastering $4 \mathrm{C}$ skills.

\section{METHOD}

In order to achieve the research objectives, research was conducted using the ADDIE (Analysis, Design, Develop, Implement, and Evaluate) model developed by Reiser and Mollenda. Addie's model framework is a cyclical process that develops over time and is continuous throughout the entire instructional planning and implementation process. Five stages comprise the framework, each with its own distinct purpose and function in the development of instructional design. The five stages of research implementation are as follows:

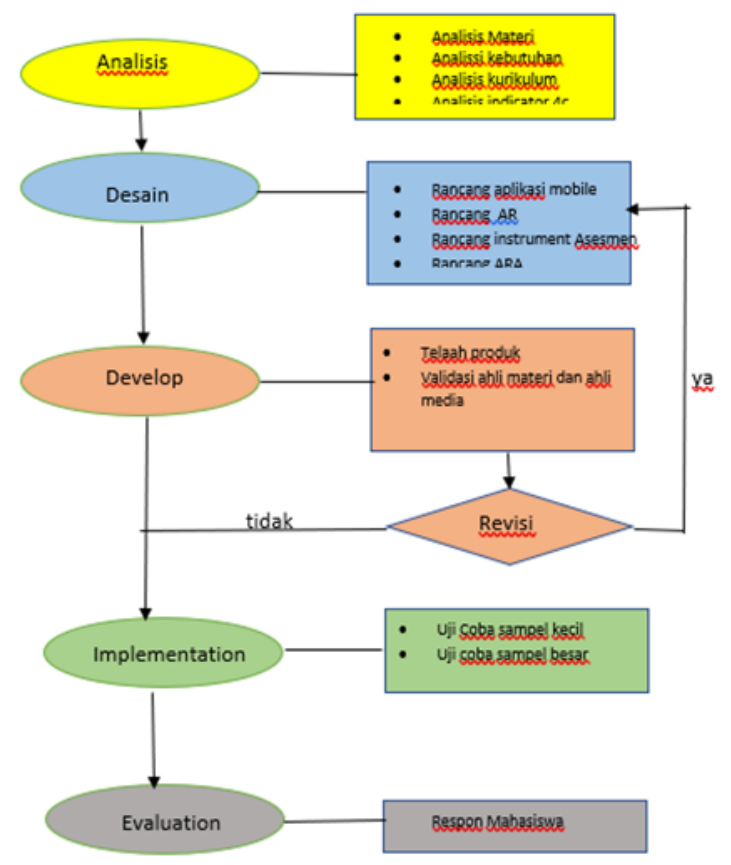

Figure 2 Stages of research.

This paper is limited to the early stages of research, namely the analysis stage. The analysis stage is an activity carried out to analyze the needs of the learning process so that the developed product meets the target. The analysis carried out is needs analysis, material analysis, and curriculum analysis. The analysis applied is based on learning needs in improving 4C skills, including appropriate and up-to-date media. Then the analysis of the material in order to direct the indicators of learning objectives that can improve $4 \mathrm{C}$ skills. Finally, curriculum analysis is to identify learning designs in accordance with the IQF curriculum implemented at Medan State University.

The information collected from the results of the analysis will then be analyzed for further description as a reference material in designing Android-based Augmented Reality (ARA) assessments that are able to improve the $4 \mathrm{c}$ skills of students in Medan State universities. This research was conducted at the Mathematics Department of Medan State University, with a random sample of students taking differential calculus courses.

\section{RESULT AND DISCUSSION}

The initial results of the research that will be explained in this paper are descriptions of the analysis stages of the 
ADDIE research stage procedure. The needs analysis was carried out from initial observations during the online learning period and through questionnaires. From the observations, it was previously explained that the learning that took place was almost 2 years online. Mathematics education students in the Class of $2020 / 2021$ who take $100 \%$ differential calculus and integral calculus courses have devices, either laptops or mobile phones, to attend lectures.

From the results of the TPMJ monitoring report, it was obtained that SIPDA online learning with a percentage of $55 \%$ and Google Classroom with $43 \%$. While using applications to support virtual interaction (video conference), lecturers chose Google Meet with a percentage of $46 \%$, Zoom with $43 \%$, and Big Blue Button SIPDA with $9 \%$. Finally, for non-e-learning support applications used by lecturers, the majority of lecturers use WhatsApp as much as $79 \%$. The monitoring results show that the online learning process is strongly supported by the use of mobile phones or laptops.

Augmented reality (AR) is a new thing that has been introduced to students. The use of Augmented Reality is very useful for interactive and real learning media and directly by students. In addition, learning media using Augmented Reality can increase students' interest in learning because of the nature of Augmented Reality, which combines the virtual world with the real world directly [19]. In previous research, AR learning media has been developed using smartphones. The students' response to the use of AR media is that AR media is interesting, especially since it has just been introduced to them [20].

The evaluation process carried out so far only uses available media such as sending questions in WA, GCR or SIPDA. From the results of TPMJ Mathematics monitoring, it was found that $34.33 \%$ of students stated that they were very satisfied and $46.50 \%$ of students stated that they were satisfied with the evaluation process carried out by the lecturer. However, there are still more than $15 \%$ of students stating that they are not satisfied with the process.

The results of the needs analysis using a questionnaire given to students who have taken the 2020 differential calculus course are obtained as Table 1 .

Table 1. Student Needs Analysis.

\begin{tabular}{ll}
\hline & \multicolumn{1}{c}{ Analysis Questions } \\
\hline 1. & $100 \%$ of students answered that they have android as an online learning tool \\
2. & $72 \%$ of students answered that they had no difficulty using LMS as an online learning medium \\
3. & $100 \%$ of students have experienced Augmented Reality \\
4. & $44 \%$ of students are satisfied with the online learning instrument system that has been going \\
on so far & \\
5. & $84 \%$ Students want evaluation instruments that are practical and can be used anywhere \\
\hline
\end{tabular}

From the results of the questionnaire analysis of students, it appears that all of the students are familiar with AR as a learning medium. However, there are still a small number of students who are satisfied with the evaluation system, which so far only uses questions that are sent in the form of a word or Google form and then sent back to the lecturer via SIPDA, GCR or WA. Students expect practical evaluation instruments. Because students have been familiar with $\mathrm{AR}$, the assessment medium that utilizes AR is deemed able to answer the student's desire for a practical evaluation medium using Android. This is supported by $100 \%$ of students who already have an android. The use of AR is supported by previous research by researchers who have developed AR media and received positive responses from students who have used it.

At the Curriculum Analysis Phase, identification of basic competencies that must be possessed in the Differential Calculus course in the IQF curriculum is carried out, as well as understanding the breadth of the material and describing basic competencies into several indicators. Material analysis was carried out to analyze the material and its implementation with the evaluation tasks given in accordance with the Indonesian National Qualifications Framework (KKNI) curriculum, which refers to the learning outcomes of the graduate profile. KKNI expects graduates to produce graduates who are able to compete with the global market of the 21 st century. So, in the preparation of materials, it is necessary to harmonize with the demands of the 21 st century, namely $4 \mathrm{C}$ skills (Communication, Collaboration, Critical Thinking and Problem Solving, Creativity and Innovation).

In the Differential Calculus course, there are several materials, including real number systems, functions, limits, and continuous and differential. In accordance with the IQF curriculum, each material must implement 6 KKNI tasks. The evaluation instruments that have been prepared are also integrated into the $4 \mathrm{C}$ skills. following $4 \mathrm{C}$ skills according to $\mathrm{P} 21$ and the opinion of experts [21]. 
Table 2. 4C skills according to $\mathrm{P} 21$ and the opinion of experts

\begin{tabular}{|c|c|c|}
\hline Skills & $\begin{array}{l}\text { Skill } 4 \text { C's } \\
\text { according to P21 (reduce) }\end{array}$ & Skill 4 C's of the experts \\
\hline Critical thinking & $\begin{array}{l}\text { 1. Using inductive } \\
\text { reasoning or deductive } \\
\text { reasoning } \\
2 \text {. Analyzing the } \\
\text { interrelationships of each } \\
\text { part of the whole to } \\
\text { produce a complex system } \\
3 \text {. Analyze and evaluate } \\
\text { the facts. } \\
4 \text {. Draw conclusions } \\
\text { based on the results of the } \\
\text { analysis } \\
5 \text {. Resolve } \\
\text { unusual/common problems } \\
\text { with conventional and } \\
6 \text {. } \\
\text { innovative ways }\end{array}$ & $\begin{array}{l}\text { R. H. Enis identified } 12 \text { critical thinking indicators } \\
\text { that } \\
\text { grouped into five major activities as follows: } \\
\text { a) Give a simple explanation } \\
\text { b) Build basic skills, } \\
\text { c) Inferring which consists of deductive or } \\
\text { inductive activities } \\
\text { d) Provide further explanation } \\
\text { e) Set strategy and technique }\end{array}$ \\
\hline Creative & $\begin{array}{l}\text { 1. Creating new ideas } \\
\text { 2. Expanding basic } \\
\text { ideas/concepts to enhance and } \\
\text { maximize creative efforts } \\
\text { 3. Develop and convey new } \\
\text { ideas to others effectively } \\
\text { Apply creative ideas as a real } \\
\text { contribution in life }\end{array}$ & $\begin{array}{l}\text { Sharp (Briggs and Davis, 2008) identified several aspects of } \\
\text { creative thinking, namely novelty, productivity, and impact or } \\
\text { benefit. Novelty refers to a unique problem-solving strategy. } \\
\text { Novelty does not have to be associated with completely new } \\
\text { ideas, but new according to students. When a student finds a } \\
\text { problem solution for the first time, he has } \\
\text { find something new, at least for himself. Productivity refers to } \\
\text { constructing as many ideas as possible, whether they are new } \\
\text { or not. While the impact or benefit refers to the usefulness of } \\
\text { an idea. In the context of learning, one form of this impact is } \\
\text { the increase in students' self-confidence after being able to } \\
\text { solve new problems. This impact or benefit component is } \\
\text { important to mention because no matter how new a product is, } \\
\text { if it is not useful or even } \\
\text { detrimental, the product cannot be categorized as creative. }\end{array}$ \\
\hline Communication & $\begin{array}{l}\text { 1. Expressing thoughts or ideas } \\
\text { through oral, written } \\
\text { or nonverbal } \\
\text { 2. Using communication for } \\
\text { various purposes (eg informing, } \\
\text { instructing, motivating or } \\
\text { inviting) } \\
\text { 3. Using various media or } \\
\text { technology in learning }\end{array}$ & $\begin{array}{l}\text { According to NCTM (1989) mathematical communication is } \\
\text { more emphasized on } \\
\text { students' abilities in terms of: } \\
\text { (1) Reading and writing mathematics and interpreting the } \\
\text { meaning and ideas of the writing. } \\
\text { (2) Reveal and explain } \\
\text { their thoughts about mathematical ideas and their } \\
\text { relationships. (3) Formulate mathematical definitions and } \\
\text { make generalizations found through investigations. (4) } \\
\text { Writing mathematical presentations with understanding. } \\
\text { (5) Using vocabulary/language, mathematical structure } \\
\text { notation to present ideas, describe relationships and create } \\
\text { models. (6) Understanding, interpreting, and evaluating ideas } \\
\text { presented orally, in writing or in visual form. (7) Observing } \\
\text { and making conjectures, formulating questions, collecting and } \\
\text { assessing information. (8) Produce and serve } \\
\text { convincing argument }\end{array}$ \\
\hline
\end{tabular}




\begin{tabular}{|c|c|c|}
\hline Collaboration & $\begin{array}{l}\text { 1. Demonstrate the ability to } \\
\text { work effectively in groups } \\
2 \text {. Accept the division of } \\
\text { responsibilities and contribute } \\
\text { in completing group } \\
\text { assignments } \\
\text { Provide input and show } \\
\text { mutual respect for each other }\end{array}$ & $\begin{array}{l}\text { According to Hari Srinivas (2012: 1), there are five elements } \\
\text { that must be met in collaborative learning, including: a) } \\
\text { positive interdependence, that is, each group member is bound } \\
\text { to work together in achieving goals. b) individual } \\
\text { responsibility, namely all students in the group are responsible } \\
\text { for doing the tasks that are their own part and mastering all the } \\
\text { material that must be studied; } \\
\text { c) face-to-face interaction, i.e. even though each group } \\
\text { member does his or her part of the task individually, some } \\
\text { tasks must be done interactively with other members by } \\
\text { providing reasoning, input, and conclusions related to the } \\
\text { material being studied and more importantly they can teach } \\
\text { each other and support; d) application of collaboration skills, } \\
\text { where students are encouraged and assisted to develop a sense } \\
\text { of trust, leadership, decision making, communication, and } \\
\text { skills in managing conflict; e) group process, i.e. group } \\
\text { members determine group goals, periodically assess what they } \\
\text { have done as a group, and identify changes that must be made } \\
\text { in order to carry out the task next more effective. }\end{array}$ \\
\hline
\end{tabular}

\section{CONCLUSION}

This research is focused on needs analysis, curriculum analysis, and material analysis. This research has implications for researchers to change the form of evaluation instruments according to the online learning process, with the use of androids, which are owned by all students, in the hope of being more flexible and interactive and in line with the demands of the development of the 21 st century.

Based on the results and discussion of this study, it shows that the development of an Augmented Reality Assessment is needed as a continuation stage of the development of AR media. Needs analysis shows that $100 \%$ of students have androids and students want learning media that is easy for them to use anywhere at any time and supports independent learning. In accordance with the IQF curriculum, by implementing 6 tasks and being integrated with the demands of $21 \mathrm{st}$ century skills, the assessment prepared will adjust to the 4C skill indicators. It is necessary to develop an Androidbased Augmented Reality (ARA) assessment to develop $4 \mathrm{C}$ skills in college students.

\section{ACKNOWLEDGMENTS}

The author gratefully acknowledge financial support from BOPTN LP2M Medan State University 2021.

\section{REFERENCES}

[1] Artobatama, I., Hamdu, G., \& Giyartini, R. Analisis Desain Pembelajaran STEM berdasarkan Kemampuan 4C di SD. Indonesian Journal of Primary Education, 4(1), 2020, pp. 76-86.
[2] Atsani, K. L. G. M. Z. Transformasi media pembelajaran pada masa Pandemi COVID-19. AlHikmah: Jurnal Studi Islam, vol. 1(1), 2020, pp. 82-93.

[3] Zubaidah, S. Mengenal 4C: Learning and innovation skills untuk menghadapi era revolusi industri 4.0. In 2nd Science Education National Conference (Vol. 13), 2018

[4] Saleh, S. E. Critical thinking as a 21st century skill: conceptions, implementation and challenges in the EFL classroom. European Journal of Foreign Language Teaching, 2019.

[5] Nuryanti, L., Zubaidah, S., \& Diantoro, M. Analisis kemampuan berpikir kritis siswa SMP. Jurnal Pendidikan: Teori, Penelitian, dan Pengembangan, 3(2), 2018, pp. 155-158.

[6] Nyihana, E., Astuti, P., \& Prasetyo, Z. The Success of Picture Story Books in SD Science on Student Critical Thinking. In International Conference on Teacher Training and Education 2018 (ICTTE 2018) (pp. 403-406). Atlantis Press, 2018.

[7] Bakrun,. Peningkatan proses pembelajaran dan penilaian pembelajaran abad 21 dalam meningkatkan kualitas pembelajaran SMK, 2018.

[8] Okoro, E., Washington, M. C., \& Thomas, O. The impact of interpersonal communication skills on organizational effectiveness and social self-efficacy: A synthesis. International Journal of Language and Linguistics, 4(3), 2017, pp. 28-32.

[9] Nakano, T. D. C., \& Wechsler, S. M. Creativity and innovation: Skills for the 21st Century. Estudos de Psicologia (Campinas), 35(3), 2018, pp. 237-246.

[10] Aswasulasikin. Persepsi Mahasiswa Terhadap Kuliah Daring dimasa Pandemi Corona Virus Disease 
(COVID-19). SALAM Jurnal Sosial Dan Budaya Syar'i, 7(10), 2020, 7- 12.

[11] Darari, M. B., \& Firdaus, M. Development of Teaching Materials Based "Activity or Resources" At Sipda Unimed to Enhance Students Learning Behavior. In Journal of Physics: Conference Series Vol. 1462, No. 1, 2020 p. 012022.

[12] Siregar, N., \& Manurung, S. L. Analysis of The Learning Motivation of Students in Mathematics Education Online Learning, State University of Medan. In Journal of Physics: Conference Series (Vol. 1819, No. 1, 2021, pp. 012069).

[13] Siregar, T. M., Frisnoiry, S., \& Siregar, N. Virtual Video Aid Web-Based E-Learning. Solid State Technology, 63(5), 2020, pp. 8089-8097

[14] Aisyah, D. N., Ingtiyasningsih, P., \& Ngazizah, N. Media Berbasis Android Untuk Pembelajaran Dimasa Pandemi Covid-19. In SEMINAR NASIONAL PENDIDIKAN DASAR (Vol. 3), 2021.

[15] International Telecommunication Union. ICT FACTS AND FIGURES 2017. International Telecommunication Union, 2017.

[16] Firdaus, M., Darari, M. B., \& Azis, Z. Designing Interactive Videos in Online Multivariable Calculus Course to Support Student's Critical Thinking. In Journal of Physics: Conference Series (Vol. 1819, No. 1, 2021, pp. 012057).

[17] Munawaroh, R. Z., Prastowo, A., \& Nurjanah, M. Efektivitas Penilaian Pembelajaran Menggunakan Google Form pada Pembelajaran Daring. JISIP (Jurnal Ilmu Sosial dan Pendidikan), 5(3), 2021.

[18] Frisnoiry, S., Siregar, T. M., \& Taufik, I. ELearning Technology: Kahoot Application as a Learning Evaluation Tool. Solid State Technology, 63(5), 2020, pp. 4396-4404.

[19] Mustaqim, I., \& Kurniawan, N. Pengembangan Augmented Reality Sebagai Media Pembelajaran Pengenalan Komponen Pneumatik Di Smk. Jurnal Pendidikan Teknologi dan Kejuruan, 14(2), 2017.

[20] Elfitra, Mansyur, A., \& Taufik, M. I. Student Perceptions of Augmented Reality (AR) Media in Calculus Courses. In Journal of Physics: Conference Series (Vol. 1819, (1), 2021, pp. 012033.

[21] Setiyawati, E. D., Sunardi, S., \& Kurniati, D. Pengembangan Indikator 4 C's Yang Selaras Dengan Kurikulum 2013 Pada Mata Pelajaran Matematika SMP/MTs Kelas VIII Semester 2. KadikmA, 8(3), 2017, pp134-144. 